\title{
固定式振動水柱型波浪発電装置のシステム・ シミュレーションの実海域試験との比較
}

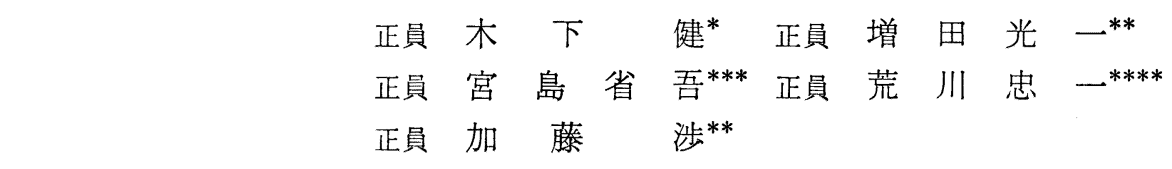

Comparison of the System Simulation for a fixed O.W.C. Type Wave

Energy Absorber with Results of the Real Sea Trial

by Takeshi Kinoshita, Member

Shogo Miyajima, Member

Wataru Kata, Member
Koichi Masuda, Member

Chuichi Arakawa, Member

\section{Summary}

The system simulation for a fixed O.W.C. type wave evergy absorber was proposed and have been studied. In this simulation, the form of air-chamber and turbine were refered to what was used in the real sea trial at SANZE. Since the device was fixed in very shallow water, the nonlinearity of hydrodynamic force on O.W.C. must be discussed.

In this paper, the authors try to know whether equations and performances of turbine used in the system simulation are appropriate or not. Furthermore, they carry out experiments by using a small model, and consider nonlinearity of hydrodynamic forces on O.W. C. on the basis of experimental results.

\section{1 緒言}

海洋科学技術センター (JAMSTEC) と三井造船は, 1983 84 年に三瀬に打いて固定式振動水柱型波浪発電 装置の実海域試験を行った。著者らは前報で1),2)，その システム・シミュレーション法を示した。そこで, この シミュレーションの有効性を検証するため, 実海域試験 のデータを JAMSTEC と三井造船の御厚意により借用 し, 解析を試みた。タービン回転数, 発電出力, 空気室 内圧力, 内部水面変位は計測されていたが, 入射波は計 測されていなかった。したがって, システム・シミュレ ーションの流体力に関する部分の検証は不可能であっ た。そこでタービン回転数と空気室内圧力の関係, 圧力 と内部水面变位との関係のみを計算値と比較してみた。 その結果をここに報告し, 今後の問題点を整理してみ

\footnotetext{
* 東京大学生産技術研究所第 2 部

** 日本大学理工学部

*** 日本大学大学院

**** 東京大学工学部
}

る。

流体力に関しては, 上記の理由で実海域データとの比 較は出来ないが, 実海域試験の水深が約 $3 \mathrm{~m}$ の極浅海 であるため, 線形計算による流体力には何らかの修正を 必要とするものと考兄られる。この極浅海でのエネルギ 一吸收特性を調べるため, 水槽模型実験を行い簡便な修 正法を試みたので, その結果を付録に示し, 参考に供す る。

\section{2 タービン性 能}

今回のシミュレーション計算には, タービン性能の影 響を調べるためにウェルズタービンの性能として, 一様 流中で計測された，

（1） 8 枚矩型翼でソリディティが 0.7 の小型模型タ ービンに対するもの1),

(2) JAMSTEC が計測した実機のタービンに対す るもの (ソリディティ 0.7 のガイドベーン付) $)^{3)}$,

（3）そして, 実機のものを正確に縮小した模型タ一 ビンに対するもの, 


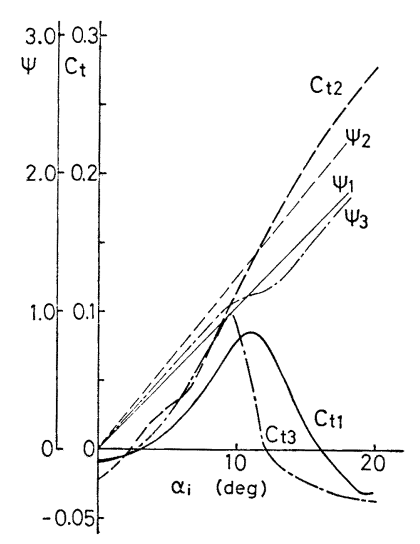

Fig. 1 Performances of each turbines

の 3 種類の実験結果を用いた。トルク係数, 差圧係数の 結果を各々, $C_{t_{1}}\left(\alpha_{i}\right), \phi_{1}\left(\alpha_{i}\right), C_{t 2}\left(\alpha_{i}\right), \psi_{2}\left(\alpha_{i}\right), C_{t 3}$ $\left(\alpha_{i}\right), \psi_{3}\left(\alpha_{i}\right)$ として Fig. 1 に示す。添字 1 3 3 , 上 記の (1)〜 (3) 亿対応する。

ここで，JAMSTEC の実機のタービンで計測したト ルク係数には，相対流入角 $\alpha_{\imath}$ が $20^{\circ}$ 以下で失速現象 が見られないが，小型模型実験では（1)，（3）共に失 速域が存在している。この原因としては，小型模型実験 が乱れの少ない空気流中で行っているのに対し, 実機タ ービンを用いた実験では空気流の乱れやガイドベーンな どによる影響を含んでいるためと考えられる。

\section{3 空気室内圧力が与えられた場合の シミュレーション}

三瀬で行われた実海域試験では, タービン回転数, 発 電出力就よび空気室内圧力, 内部水面変位が計測されて いる。後でも述べるように, 内部水面変位の記録には若 干問題が含まれていると考光, シミュレーションは空気 室内圧力を入力として行らことにした。な祘，入射波高 は計測されていない。そこで, 空気室内圧力が与えられ た場合のシミュレーション計筫の方法を以下に示す。

まず，タービンが高速回転状態にあると仮定すると， 空気流速 $v(t)$ は,

$$
v(t)=\left\{p(t)-p_{0}\right\} /\left\{0.5 \rho_{a} \psi_{j 0} R_{T} w_{T}(t)\right\}
$$

で線形近似することができる2)。ここで， $p(t)$ は空気室 内圧力, $p_{0}$ は大気圧, $\rho_{a}$ は空気密度, $R_{T}$ はタービン チップ半径, $w_{T}(t)$ は回転角速度であり, $\psi_{j 0}(j=1 \sim 3)$ は Fig. 1 の各々の差圧係数 $\psi_{j}\left(\alpha_{\imath}\right)$ の原点での相対流 入角 $\alpha_{i}$ に対する傾きである。

次に, タービンの回転トルク $T_{0}(t)$ は,

$$
\begin{aligned}
T_{0}(t)= & 0.5 \rho_{a} R_{T} A_{T} C_{t j}\left(\alpha_{i}\right) \\
& \times\left\{\left(R_{T} w_{T}(t)\right)^{2}+v^{2}(t)\right\}-T_{L}
\end{aligned}
$$

で与えられる1)。ここで， $A_{T}$ は空気流路面積， $T_{L}$ は負
荷・損失トルクである。なお，今回の実海域試験では発 電出力一定の制御を行っているので, シミュレーション でも発電出力は一定として, 回転角速度に対応して負荷 トルクを変化させている。そして, タービン回転角速度 の変化率は,

$$
d w_{T}(t) / d t=T_{o}(t) / I
$$

でありＩは慣性モーメントである。

実海域試験では, 空気室内圧力として「 $p(t)-p_{0} 」 か ゙$ 計測されているので, この時刻歷を入力とし, 回転角速 度の初期值を与えてシミュレーションを行らと空気流速 とタービン回転角速度を求めることができる。

さらに, 空気室内空気の圧縮性を考慮した場合之しな い場合の内部水柱変位の計算を行った。空気室内の状態 を表わす方程式を以下に示す。最初に, 空気室内空気の 圧縮性を考慮して断熱変化を仮定した場合は,

$$
\begin{aligned}
-p(t) A_{w} \dot{z}(t)+c_{v}\left[\dot{p}(t)\left\{V_{0}-A_{w} z(t)\right\}\right. \\
\left.-p(t) A_{w} \dot{z}(t)\right] / R+2 v(t) A_{T} p_{e} c_{p} / R=0(4) \\
p_{e}=\left\{\begin{array}{lll}
p(t) & \text { for } & v(t)>0 \\
p_{0} & \text { for } & v(t)<0
\end{array}\right.
\end{aligned}
$$

であり ${ }^{2)}$, ここで $A_{w}$ は内部水柱の水線面積, $V_{0}$ は空 気室容積, $c_{v}, c_{p}, R$ は各々, 定容比熱, 定圧比熱, 気体 定数, $z(t)$ は水柱上下摇れ変位である。次に等温变化 を仮定すると，

$$
-2 A_{T} p(t) v(t)=\dot{p}(t)\left\{V_{0}-A_{w} z(t)\right\}-A_{w} p(t) \dot{z}(t)
$$

である2)。また，室内空気の圧縮性を無視した場合は，

$$
\dot{z}(t)=v(t) / k_{T}, \quad k_{T}=A_{w} /\left(2 A_{T}\right)
$$

となる2。以上の式を圧力の時刻歴を入力として解くこ とにより, 各々の場合の水柱変位を計算することができ る。

\section{4 結果および考察}

今回, 計算結果との比較に用いた実海域試験のデータ は，三井造船が収録したものを用いた4)。これは，空気 室内水面変位をフロート式波高計で計測したものであ る。これらの計測データのらち, 発電出力の異なる 3 ケ ースを例にシミュレーション結果と比較し，タービン性 能曲線や関係式の妥当性の検討を行った。

\section{1 タービン性能曲線の検討}

Fig. 2 亿, 実海域試験で計測された圧力の時刻歷を示

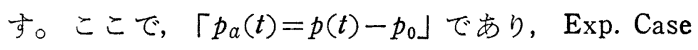
$\mathrm{A} \sim \mathrm{C}$ までの圧力の時刻歴を入力として各々のケースの シミュレーションを行った。Fig. 3 に, Exp. Case Aの 場合のタービン角速度の計算結果定実海域試験の結果と 比較して示す。シミュレーションの Type 1〜3は2章 の（1）（3）に対応するタービン性能を用いた結果で 岕り, 発電出力は $64 \mathrm{sec}$ まで $0 \mathrm{~kW}$ ，それ以降 $6 \mathrm{~kW}$ 

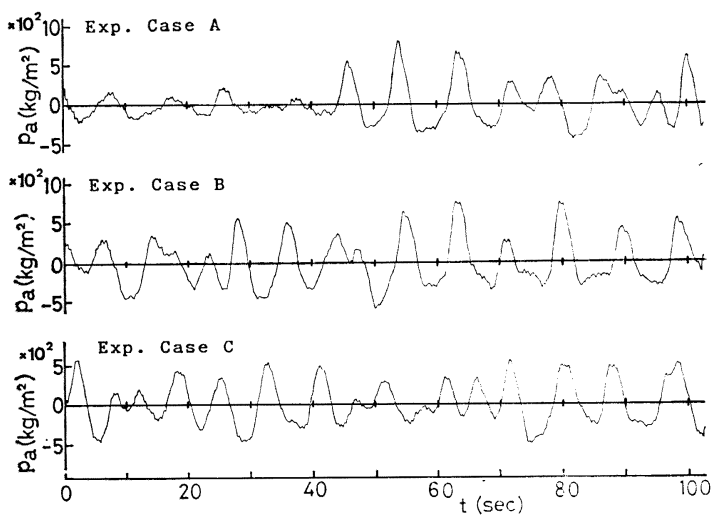

Fig. 2 Time history of pressure in air-chamber obtained by real sea experiments

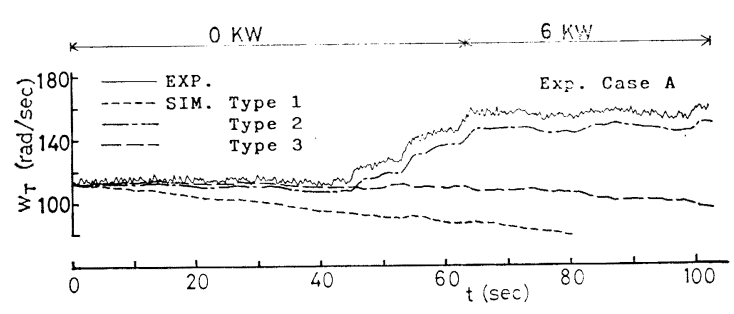

Fig. 3 Time history of angular velocity obtained by experiment case $\mathrm{A}$ and simulations
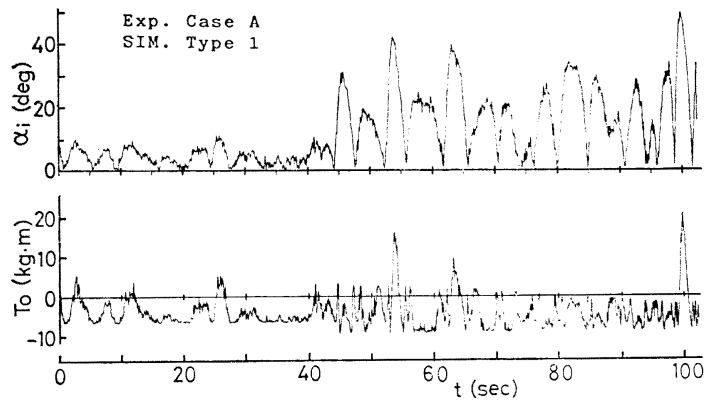

Fig. 4 Time history of fluid inlet angle and torque obtained by simulation type 1
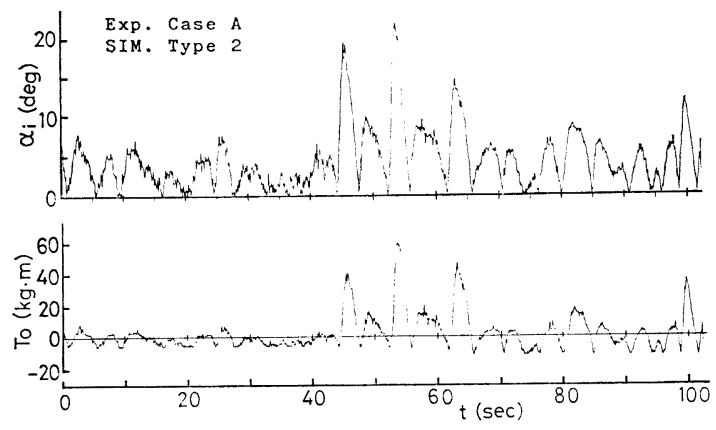

Fig. 5 Time history of fluid inlet angle and torque obtained by simulation type 2
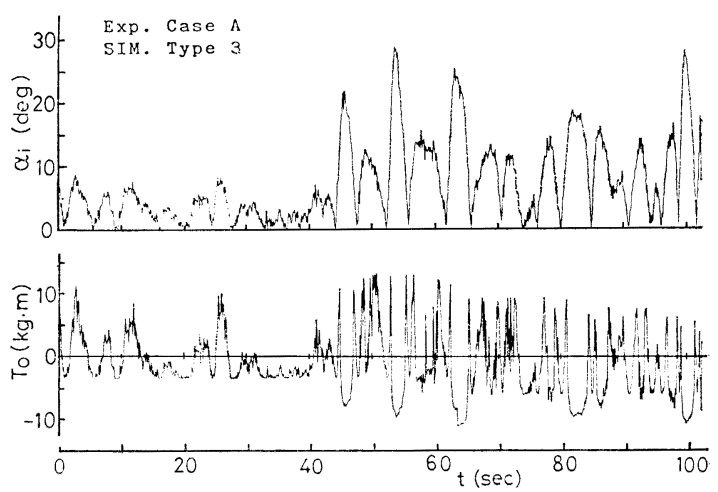

Fig. 6 Time history of fluid inlet angle and torque obtained by simulation type 3

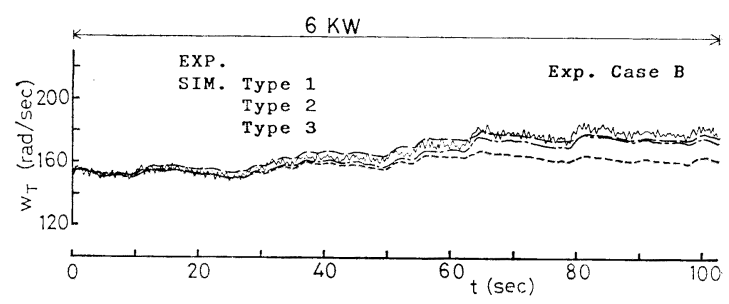

Fig. 7 Time history of angular velocity obtained by experiment case $B$ and simulations

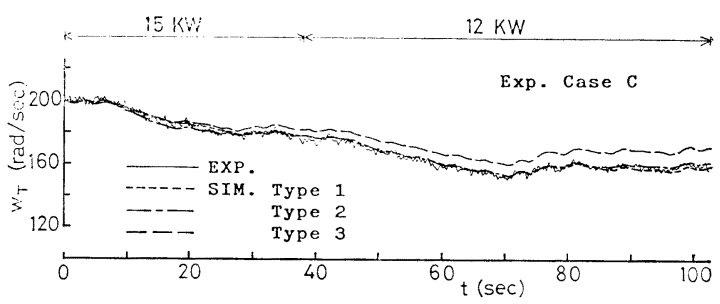

Fig. 8 Time history of angular velocity obtained by experiment case $\mathrm{C}$ and simulations

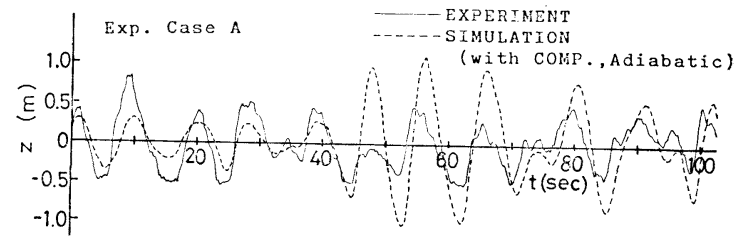

Fig. 9 Time history of heaving displacement obtained by experiment case $\mathrm{A}$ and simulation

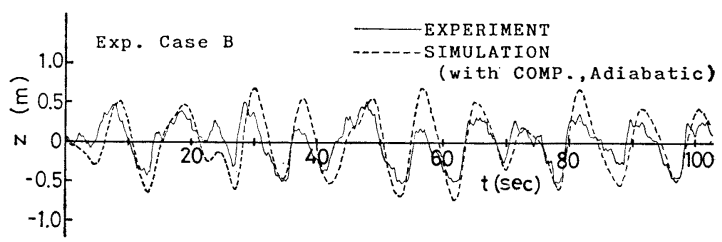

Fig. 10 Time history of heaving displacement obtained by experiment case $B$ and simulation 


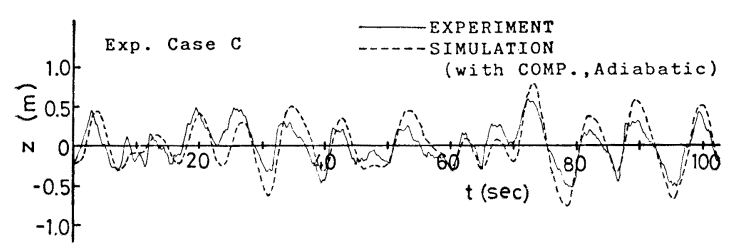

Fig. 11 Time history of heaving displacement obtained by experiment case $\mathrm{C}$ and simulation

である。Type 2 のシミュレーションは実験值と良好な 一致を示すが, 他の 2 つの Type は実験值との差が大 きい。特に Type 1 の回転角速度は低下を続け， $t=45$ $\sec$ 位からの上昇が見られない。これらの原因を検討す るために, 各々の Type について相対流入角 $\alpha_{i}$ と夕 一ビン回転トルク $T_{0}$ の時刻歷を求めた。その結果を Fig. 4〜6 に示す。Type 1 のトルク係数は, $\alpha_{\imath}$ が $10^{\circ}$

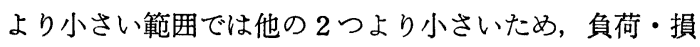
失トルクを考えると回転トルクの負の領域が大きくなり 回転が低下し，高速回転域を脱してしまう。また, Type 2 と 3 では相対流入角 $\alpha_{i}$ の時刻歴はほ医等しいが, Type 3 のトルク係数は， $\alpha_{\imath}$ が約 $10^{\circ}$ で失速するため 回転トルクが大きくならず, $t \fallingdotseq 45 \mathrm{sec}$ からの回転数は 低下してしまう。

次に Exp. Case B, C についても同様な比較を行った。 角速度の時刻歷を Fig. 7,8 に示し, その時の発電出力 は図中に示した通りである。これらのシミュレーション においては, 相対流入角 $\alpha_{\imath}$ が失速角度まで達していな いため, Type 1〜3 はほぼ同様な結果となったが中で も Type 2 が最も良好な一致を示している。

以上, タービン角速度の実海域試験データとシミュレ ーション計算結果とを比較した結果, 相対流入角が失速 角度以下であれば, タービン回転数のシミュレーション はタービン性能 (1)〜 (3) のどの係数を用いてもほぼ 正確に行うことができることがわかった。しかしなが ら，相対流入角が失速角度より大きい領域を含むような 場合には，実機タービンで計測したタービン性能を用い た場合にのみ良好な計算結果を得ることができた。以上 のことより，実機を想定した場合のタービン回転のシミ ニレーションに用いるタービン性能は, 出来れば実機タ ービンに対するものを用いるのが良い。また，本計算に 用いた負荷・損失トルクの見積り,およびタービンの慣 性モーメントの值が妥当であることがわかった。

\section{2 空気室内空気に対する関係式の検討}

Fig. 9〜11 に Exp. Case A〜C のフロート式波高計 で計測された空気室内部水面変位の時刻歴と, 室内空気 の圧縮性を考慮して断熱変化を仮定した場合のシミュレ ーション結果とを比較して示す。シミュレーション計算
の結果としては, 圧縮性・断熱変化の場合のみを示した が，他の $2 つ の$ 条件で行った計算もほとんど等しい結果 であった。その原因は，入力した圧力波形の平均周期が 長く, タービンの回転数も比較的低いために空気室内空 気の圧縮性による影響が小さいためである。また，波高 計のデータとシミュレーション結果とは, 定量的にはあ まり良い一致を示さなかった。これは, シミュレーショ ン計算に括いては振動水柱を等価浮体で近似し, その上 下摇れのみを取り扱っているのに対し, 実際の内部水面 は種々のモードで運動しており波高計がその一点のみの 変位を計測しているためと思われる。例えば Fig. 2 の Exp. Case A の場合, 圧力は $t=45 \mathrm{sec}$ で大きくなって いるが, Fig. 9 の水面変位の実験結果には顕著な变動は 見られない。

しかしながら，全般的に見ると水面変位のオーダーや 傾向はほぼ一致している。

\section{5 結}

\section{言}

シミュレーションによる計算結果と実海域試験の結果 との比較・検討を行った結果よりわかったことを以下に 整理して述べる。

1）一様流中で得られたタービンの性能曲線を用いて 実海域でのタービン回転数のシミュレーションは可能で あるが，小型模型タービンにより計測された，空気室か ら入り込む空気流の乱れやガイドベーンの影響を含まな いタービン係数を用いてシミュレーションを行うと, 失 速域の関係で実海域試験の結果と異なってくる場合があ る。したがって, 可能であれば実機のタービンを用いて 計測したタービン係数を用いるのが好ましい。

2）本計算に用いた負荷・損失トルクの見積り, およ びタービンの慣性モーメントの值が妥当であることがわ かった。

3）空気室内空気の圧縮性に関する関係式の妥当性 は, 実海域試験での波周期と振幅の関係で検証できなか った。また, 内部水面变位と圧力との関係式も実海域試 験における内部水面変位の計測法と数值計算モデルの相 違により検証することはできなかった。しかし，内部水 面変位は定性的には㬰験值と推定值とはほぼ一致した。

また付録に，極浅海域での特性が，波強制力を修正す る簡便な方法で, 少なくとも今回行った規則波の実験值 については，ほぽ推定できることを示した。

しかし, 実海域試験での入射波高, 内部水面変位のデ ータが十分でなかったため, システム・シミュレーショ ンのすべての部分の妥当性が検証されるには至らなかっ たのは残念である。今後の実海域試験では, それらのデ 一タが計測されることが望ましい。そして, タービンの 性能曲線についても空気流の乱れの制御などにより，小 
型模型の結果から実機性能の推定が可能となるような実 験方法の開発が望まれる。

\section{謝 辞}

本研究に方たり，多大なる御助言をいただいた東京大 学生産技術研究所の前田久明教授, また, 快く実海域試 験のデータを提供していただいた三井造船，JAMSTEC の関係者の方々に深く感謝いたします。

\section{参考文 献}

1）木下 健, 増田光一, 宮島省吾, 加藤 涉 : 固定 式振動水柱型波浪発電装置のシステム・シミュレ ーション, 日本造船学会論文集, 第 156 号 (1984).

2）木下 健，増田光一，宮島省吾，加藤 涉 : 固定 式振動水柱型波浪発電装置に対する空気室内空気 の压縮性の影響について，日本造船学会論文集， 箱 157 号 (1985).

3）驚尾幸久, 堀田 平, 宫崎武晃, 益田善雄 : タン デムウェルズタービンの実機性能試験, 第 1 回波 浪エネルギー利用シンポジウム，海洋科学技術七 ンター (1984).

4）菊池省吾：沿岸固定空気タービン式波力発電，海 洋エネルギー一商業化の時期と条件——に関す るシンポジウム, ECOR 日本委員会 (1985).

\section{付録 極浅海域での水槽模型実験}

本システム・シミュレーションでは, 振動水柱を等価 浮体と考古，それに働く流体力を線形計算で求めている が，本論文で比較している三瀬の実海域試験のような場 合，水深が $3 \mathrm{~m}$ に対して入射波高が $2 \mathrm{~m}$ 位となり，流 体力の推定精度が悪いことが当然予測される。赛海域で の計測が行われると一番良かったのであるが，計測の困 難さから入射波は計られなかった。そのため，実海域試 験との比較は出来ないが, 参考のため水槽模型実験の結 果をここに述べる。

実験は, 架気室の $1 / 14$ の小型模型を使用し, 2 次元 水槽で行った。模型断面を Fig. A 1 に示す。水深は 21 $\mathrm{cm}$ (実機想定 $3 \mathrm{~m}$ ) で規則波実験を行った。入射波周 期は $1.4 \mathrm{sec} \sim 2.4 \mathrm{sec}$ （実機想定 $5.2 \mathrm{sec} \sim 9.0 \mathrm{sec}$ ）と し, 砕波直前の波高を用いた。空気室内水面に加わる負 荷としては，オリフィス負荷を考学，オリフィス面積と 内部水面面積との比，すなわ門口比 $r$ は， $1 / 100$, $1 / 125 ， 1 / 150,1 / 175$ の 4 種類とした。計測項目は, 空 気室内圧力と内部水面変位であり, 水面変位は 3 点で計 測した值を平均して求めた。さらに一次変換効率を計算 した。

実験より得られた内部水画上下摇れ振幅を Fig. A2 に示す。横軸は，沖波での然次元波数 $K B=\omega^{2} B / g$ であ り， $\omega$ は入射波円周波数，Bは空気室水線幅で $467 \mathrm{~mm}$, $g$ は重力加速度である。黒点が実験值であり，細い線で 示した CAL. 1 は, 振動水柱に加わる線形流体力を用い て解析を行った理論值である。図よりわかるよらに，実 験值と CAL. 1 の対応は良くない。そこで本論では, 付
加質量, 造波ダンピングの値は線形理論の值のまま変化 せずに, 強制力が減少しており, その減少率は周波数の 関数であり，波高に無関係であると仮定して，その減少 率を水面変位の各実験值より求めた。それらを各周波数 ごとに平均した值を用いて解析を行った結果が，太線で 示した CAL. 2 であり，ほぼ実験値と一致している。さ らに，その減少率を用いて計算した一次変換効率の結果 を実験値と比較したのが Fig. A3 である。各記号は Fig. A1 と同様であるが, CAL. 2 は最も高周波の実験 値を除いて良く実験值の傾向を表している。

このように，三瀬のような極めて浅い場所に設置する 沿岸固定式波浪発電装置に関しては, 内部水面变位の予 測は線形計算のみでは難しく, 設置海域を想定した小型 模型実験を行い，周波数每に波強制力の減少率を求めた 上でシミュレーション計算を行らのも一つの方法と考え る。しかし，このようにして得られた波強制力の減少率 が，どれ位波高に依存しないかとか，不規則波に対して もこの方法が有効であるかとか, 今後確認を要する問題 点は多い。

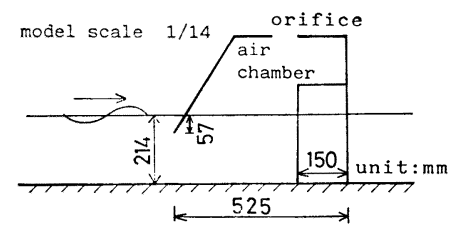

Fig. A1 Experimental model of tank test

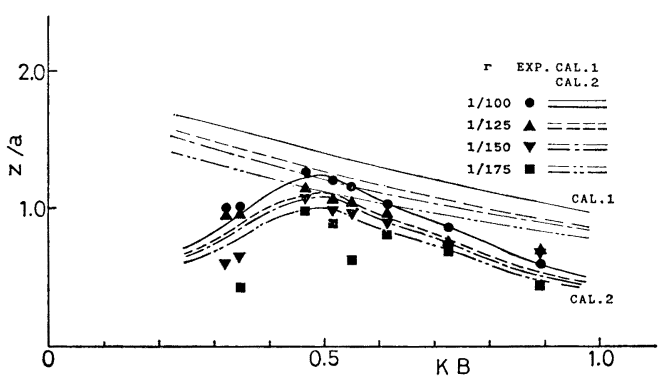

Fig. A2 Comparison of heaving amplitudes between experiment and calculations

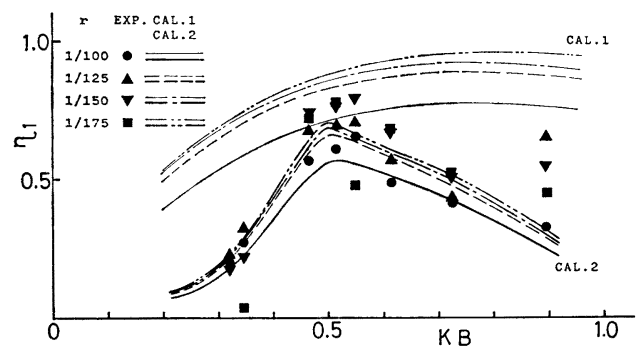

Fig. A3 Comparison of efficiency of primary energy comversion between experiment and calculations 